\title{
PENGARUH LABEL HALAL MAJELIS ULAMA INDONESIA (MUI), HARGA PADA OLEH-OLEH MAKANAN KHAS PASURUAN TERHADAP MINAT BELI DAN KEPUTUSAN PEMBELIAN
}

\author{
Muhammad Fahmul Iltiham, Muhammad Nizar \\ fahmul@yudharta.ac.id,muhammadnizar@yudharta.ac.id \\ Universitas Yudharta Pasuruan
}

\begin{abstract}
This research is an explanatory research. The location of this research is in Pasuruan Regency. Determination of the location of this study is considered on the basis of the lack of halal-labeled SME products, this study wants to examine the extent to which aspects of prices and halal labels affect consumer purchasing decisions and interests. The sampling method in this study uses convenience sampling, with a sample size of 100 respondents. Data collection techniques using consumer surveys, with a questionnaire research instrument.

The results of this study indicate that the halal label only affects consumers to foster buying interest, but does not affect consumers to make purchasing decisions. Price variables affect buying interest and purchasing decisions, while both prices and halal labels affect consumer purchasing decisions through buying interest.
\end{abstract}

Keywords: MUI Halal Label, Price, Minal Purchase, Purchase

\begin{abstract}
Penelitian ini merupakan explanatory research. Lokasi penelitian ini adalah di Kabupaten Pasuruan. Penetapan lokasi penelitian ini dipertimbangkan atas dasar minimnya produk UKM berlabel halal, penelitian ini ingin menguji sejauh mana aspek harga dan label halal mempengaruhi minat dan keputusan pembelian konsumen. Metode pengambilan sampel pada penelitian ini menggunakan convenience sampling, dengan jumlah sampel 100 responden. Teknik pengambilan data menggunakan survei konsumen, dengan instrumen penelitian kuesioner.

Hasil penelitian ini menunjukkan bahwa label halal hanya mempengaruhi konsumen untuk menumbuhkan minat beli, namun tidak mempengaruhi konsumen untuk mengambil keputusan pembelian. Variabel harga mempengaruhi minat beli maupun keputusan pembelian, sedangkan baik itu harga dan label halal
\end{abstract}


$312\}\{$ Pengaruh Label Halal Majelis Ulama Indonesia (MUI), Harga, pada

mempengaruhi keputusan pembelian konsumen melalui minat beli.

Kata Kunci: Label halal MUI, Harga, Minal Beli, Keputusan Pembelian

\section{PENDAHULUAN}

Sejalan dengan perkembangan agama Islam di Indonesia, Agama Islam pun mewajibkan pengikutnya untuk menkonsumsi makanan yang baik dan halal. batasan antara halal dan haram dalam kehidupan manusia, diterangkan jelas oleh al-Qur'an dan as-Sunnah sebagai bentuk penjagaan Allah kepada manusia, untuk menjaga kesucian diri dari hal-hal yang diharamkan dalam syariat. Karena itupula Allah tidak akan menghalalkan sesuatu kecuali yang baik dan tidak akan mengharamkan sesuatu kecuali yang jelek. ${ }^{1}$ Namun dalam praktiknya di Indonesia masih banyak sekali produk nasional yang belum memiliki sertifikat halal, terutama pada usaha kecil dan menengah. ${ }^{2}$

Mengkonsumsi produk khususnya makanan halal merupakan syarat yang ditetapkan dalam syariat Islam seperti ditegaskan dalam Al-Quran. Atas dasar itu, umat Islam sejalan dengan ajaran Islam, menghendaki supaya produk-produk yang akan dikonsumsi, dijamin kehalalan dan kesuciannya. ${ }^{3}$ Disamping itu produsen tersebut, dituntut untuk memproduksi produk-produk halal yang akan dikonsumsi oleh masyarakat Indonesia yang mayoritas agama Islam sebagai tanggung jawab keagamaannya. ${ }^{4}$

Harga juga mempengaruhi minat beli dan keputusan penjualan, terkadang produk yang berlabel halal, identik dengan istilah mahal, karena unuk proses produksinya butuh pengawasan, mulai dari bahan, cara mengolah, cara mengemas, sampai cara mempromosikan. Harga adalah nominal yang harus di bayarkan oleh konsumen terhadap penjual atas suatu barang atau jasa yang dibelinya. ${ }^{5}$

\footnotetext{
${ }^{1}$ Zulaekah, Siti, and Yuli Kusumawati. Halal Dan Haram Dalam Islam. Junal Suhuf. 2016.

2 Nizar, M. 2016. Proses Entrepreneurship, Kolaborasi Inovasi, Penciptaan Kekayaan di dalam Organisasi Bisnis. Jurnal Istiqro, 2 (2), 91-103.

${ }^{3}$ Al-Ghazali, I. Benang Tipis Antara Halal dan Haram. (Pasuruan: Putra Pelajar. 2002), 90.

${ }^{4}$ Hastuti, E. R. (2017). Analisis Penetapan Kewajaran Harga Pada Pembiayaan Rahn di Bank Mandiri Syariah. Jurnal Justisia Ekonomika: Magister Hukum Ekonomi Syariah. 5(1), 120.

${ }^{5}$ Rakhmawati, A., Kusumawati, A., Rahardjo, K., \& Muhammad, N. (2020) The role of government regulation on sustainable business and its influences on performance of mediumsized enterprises. Journal of Sustainability Science and Management. 21(3), 330.
} 
Selain itu kejelasan antara makanan halal dan haram, tentunya membuat konsumen khususnya muslim, akan semakin tenang dalam mengkonsumsinya, karena dapat memilih makanan halal tanpa ragu terdapat kandungan didalamnya. ${ }^{6}$ Dari segi lain, bahwa halal dan haram beredar menurut perputaran perundang-undangan Islam secara umum, yaitu suatu perundang-undangan yang berdiri di atas landasan demi mewujudkan kebaikan untuk umat manusia dan menghilangkan beban yang berat serta mempermudah umat manusia. ${ }^{7}$

Khusus di Indonesia terdapat sebuah lembaga khusus yang berwenang dalam menyeleksi serta mengaudit produk produk makanan yang dikonsumsi oleh umat muslim untuk menjamin kehalalannya. ${ }^{8}$ Lembaga ini adalah Lembaga Pengawasan dan Peredaran Obat dan Makanan-Majelis Ulama Indonesia (LPPOM-MUI). Lembaga ini adalah lembaga yang mengawasi peredaran makanan yang ada di masyarakat dan secara khusus memiliki wewenang untuk memberikan Sertifikasi Halal pada produk dalam kemasan.

Sertifikat Halal MUI ini merupakan syarat untuk mendapatkan ijin pencantuman label halal pada kemasan produk dari Majelis Ulama Indonesia, sehingga produsen yang telah mendaftarkan produknya makanannya ke lembaga ini serta lulus uji kehalalannya maka diperbolehkan untuk memakai label halal dalam produk kemasan tersebut. Artinya proses serta zat yang terkandung di dalam makanan tersebut telah terhindar dari hal hal yang dilarang oleh syariat. Sehingga dapat dikonsumsi dengan baik oleh umat muslim. Maka apabila terdapat suatu produk kemasan yang belum terdapat labelisasi kehalalan, secara otomatis diragukan kehalalannya dan umat Islam dapat berhati-hati dalam memutuskan untuk membeli produk tersebut. ${ }^{9}$

Ada beberapa penelitian yang berkaitan dengan minat beli dan keputusan pembelian, Rafita dengan judul Pengaruh pencantuman label halal pada kemasan mie instan terhadap minat pembelian masyarakat muslim. ${ }^{10}$

\footnotetext{
${ }^{6}$ Syahputra, A., \& Hamoraon, H. (2014). Pengaruh Labelisasi Halal Terhadap Keputusan Masyarakat Kecamatan Perbaungan Dalam Pembelian Produk Makanan Dalam Kemasan. Jurnal Ekonomi Dan Keuangan. 7(1), 81-110.

${ }^{7}$ Hamid, A. Buku Pintar Halal Haram Sehari-hari. (Yogyakarta: Diva Press. 2012), 43.

${ }^{8}$ Girindra, A. LP POM MUI Sejarah Sertifikasi Halal. (Jakarta: LP POM. 1998), 87.

9 Al-Asyhar, T. (2003). Bahaya Makanan Haram bagi Kesehatan Jasmani dan Kesucian Rohani. Jakarta: PT Al-Mawardi Prima.15

${ }^{10}$ Rafita, H. Z. (2015). Pengaruh Label Halal Terhadap Keputusan Pembelian Produk Kosmetik (Studi Pada Mahasiswi Fakultas Ekonomi Dan Bisnis Islam Angkatan 2013- 2016 UIN Raden Intan Lampung). 3(2) 74.
} 
Dari penelitian ini diketahui bahwa pencantuman label halal memberikan pengaruh sebesar $31,1 \%$ terhadap minat beli, dengan judul Pengaruh label halal dan kualitas produk terhadap kepuasan konsumen, dengan hasil bahwa label halal dan kualitas produk berpengaruh signifikan. Abdul, Ismail, Hashim, \& Johari, dengan judul Consumer decision making process in shopping for halal food in Malaysia, dengan hasil penelitian bahwa di Malaysia, semua produk makanan, minuman, harus mempunyai label halal, dan pengaruhnya sangat signifikan. ${ }^{11}$

Obyek penelitian ini adalah pengusaha oleh-oleh khas Pasuruan, khususnya makanan dan minuman, yang berjumlah 176 produk olahan makanan dan minuman di Pasuruan, dewasa ini masih banyak ditemukan peredaran produk makanan dan minuman baik yang lokal maupun yang impor, dan belum memiliki lebel sertifikat halal yang terdapat pada kemasan makanan tersebut, hal ini menunjukkan masih rendahnya kewajiban pelaku usaha untuk mengikuti ketentuan hukum yang berlaku. Di Pasuruan juga sama, banyak produk-pruduk lokal yang tidak mencantumkan lebel halal, akibatnya konsumen merawa was-was terhadap oleh-oleh yang mereka beli.

Bupati Pasuruan mengemukakan bahwa Kabupaten Krisis akan pengasawan makanan, khususnya label halal. Pasuruan merupakan kota santru, namun produk-produk yang dimilikinya tidak terdapat label halal. Bahkan dibeberapa produk hanya mencantumkan tulisan halal sebagai strategi promosi, oleh karena itu dari latar belakang tersebut peneliti tertarik untuk meneliti tentang pengaruh label halal Majelis Ulama Indonesia, harga pada oleh-oleh makanan khas Pasuruan terhadap minat beli dan keputusan pembelian.

Tujuan penelitian diantaranya untuk mengetahui, mengobservasi, mengkaji, menguji dan mengkritisi apakah label halal MUI berpengaruh secara signifikan terhadap minat beli. Untuk mengetahui, apakah harga berpengaruh secara signifikan terhadap minat beli. Untuk mengetahui, mengobservasi, mengkaji, menguji dan mengkritisi apakah label halal MUI berpengaruh secara signifikan terhadap keputusan pembelian. Untuk mengetahui, mengobservasi, mengkaji, menguji dan mengkritisi apakah minat beli berpengaruh secara signifikan terhadap keputusan pembelian. Untuk mengetahui, apakah minat beli berpengaruh secara signifikan terhadap

\footnotetext{
${ }^{11}$ Abdul, M., Ismail, H., Hashim, H., \& Johari, J. (2009). Consumer decision making process in shopping for halal food in Malaysia. China-USA Business Review.
} 
keputusan pembelian. Untuk mengetahui, mengobservasi, mengkaji, menguji dan mengkritisi apakah label halal MUI berpengaruh secara signifikan terhadap keputusan pembelian melalui minat beli. Untuk mengetahui Apakah harga berpengarus secara signifikan terhadap keputusan pembelian melalui minat beli.

\section{KERANGKA TEORI}

\section{Label Halal}

Label menurut kamus besar bahasa Indonesia (KBBI) berarti sepotong kertas (kain, logam, kayu, dan sebagainya) yang ditempelkan pada barang dan menjelaskan tentang nama barang, nama pemilik, tujuan, alamat, dan sebagainya. Label merupakan bagian sebuah produk yang membawa berita verbal tentang produk ataupun penjualan. ${ }^{12}$ Sebuah label bisa merupakan dari etiket (tanda pengenal) atau pula kemasasan yang dicantumkan pada produk. Label terbagi ke dalam tiga klasifikasi, meliputi Describtive label, Brand label, Grade label. Dalam nomor 69 tahun 1999 tentang label dan iklan pangan label pangan adalah setiap keterangan mengenai pangan yang berbentuk gambar, tulisan, kombinasi keduanya, atau bentuk lain yang disertakan pada pangan, dimasukkan ke dalam, ditempelkan pada, atau merupakan bagian kemasan pangan, yang selanjutnya dalam peraturan pemerintah ini disebut label. ${ }^{13}$

Sedangkan Dalam ketentuan umum peraturan badan pengawas obat dan makanan nomor 31 tahun 2018 tentang label pangan olahan disebutkan label pangan olahan, yang selanjutnya disebut label adalah setiap keterangan mengenai pangan olahan yang berbentuk gambar, tulisan, kombinasi keduanya, atau bentuk lain yang disertakan pada pangan olahan, dimasukan ke dalam, ditempelkan pada, atau merupakan bagian kemasan pangan. Menurut Fatmasari Sukesti \& Mamdukh Budiman, labelisasi halal adalah pencantuman tulisan atau pernyataan halal pada kemasan produk untuk menunjukkan bahwa produk yang dimaksud bersetatus sebagai produk halal. ${ }^{14}$ Menurut label makanan halal

\footnotetext{
${ }^{12}$ William, J. S. Prinsip-prinsip Pemasaran. (Jakarta: Erlangga. 2004), 264.

${ }^{13}$ Abd Latif, I., Mohamed, Z., Rezai, G., \& Kamarulzaman, N. (2013). The impact of food labeling on purchasing behavior among Non-Muslim consumers in Klang Valley. Australian Journal of Basic and Applied Sciences.

${ }^{14}$ Fatmasari Sukesti, \& Mamdukh Budiman. (2014). the Influence Halal Label and Personal Religiousity on Purchase. International Journal of Business, Economics and Law. 150-153
} 
terdiri dari tiga (3) bagian yaitu: 1) Terdapat logo halal, 2) Terdapat label komposisi, 3) Terdapat label kandungan nutrisi. ${ }^{15}$

\section{Harga}

Ferdinand, harga merupakan salah satu variabel penting dalam pemasaran, dimana harga dapat mempengaruhi konsumen dalam mengambil keputusan untuk membeli suatu produk, karena berbagai alasan. ${ }^{16}$ Alasan ekonomis akan menunjukkan harga yang rendah atau harga terlalu berkompetisi merupakan salah satu pemicu penting untuk meningkatkan kinerja pemasaran, tetapi alasan psikologis dapat menunjukkan bahwa harga justru merupakan indikator kualitas dan karena itu dirancang sebagai salah satu instrumen penjualan sekaligus sebagai instrument kompetisi yang menentukan. ${ }^{17}$

Dalam model perilaku konsumen menurut Kotler terdapat 6 keputusan yang dilakukan oleh konsumen, yaitu pilihan produk, pilihan merek, pilihan dealer, jumlah pembelian, saat yang tepat melakukan pembelian, dan metode pembayaran. ${ }^{18}$ Dalam penelitian yang dilakukan didapat indikator motivasi pembelian yang digunakan untuk mengukur variabel keputusan pembeliannya. ${ }^{19}$

\section{Minat Beli}

Purchase Intention atau minat beli menurut $\mathrm{H}$ Assel, merupakan kecenderungan konsumen untuk mengkonsumsi sesuai atau mengambil tindakan yang berkaitan dengan pembelian, dan diukur dengan tingkat kemungkinan konsumen melakukan pembelian. ${ }^{20}$ Sedangkan minat adalah sesuaitu yang tertutup (pribadi) yang berhubungan dengan sikap, individu yang mempunyai respek terhadap obyek akan mempunyai kekuatan untuk melakukan serangkaian tingkah laku untuk mendekati

\footnotetext{
${ }^{15}$ Abd Latif, I., Mohamed, Z., Rezai, G., \& Kamarulzaman, N. (2013). The impact of food labeling on purchasing behavior among Non-Muslim consumers in Klang Valley. Australian Journal of Basic and Applied Sciences. 60.

${ }^{16}$ Ferdinand, A. (2003). Manajemen Pemasaran: Sebuah Pendekatan Stratejik. Research Paper Series.

${ }^{17}$ Weenas, J. (2013). Kualitas Produk, Harga, Promosi Dan Kualitas Pelayanan Pengaruhnya Terhadap Keputusan Pembelian Spring Bed Comforta. Jurnal Riset Ekonomi, Manajemen, Bisnis Dan Akuntansi.

${ }^{18}$ Kotler. (2013). Manajemen Pemasaran Jilid 2. In Penerbit Erlangga. 226

19 Vargas-rechia, C. G., Reicher, F., Sierakowski, M. R., Heyraud, A., Driguez, H., Szymanska-chargot, M., Asadpur, G. (2015). A profile of the South African table grape market value chain. Bioresource Technology. https://doi.org/10.1016/j.jaap.2016.09.004

${ }^{20}$ H, Assle. (1992). Consumer Behavior \& Marketing Action. PWS: Kent publishing company. 60
} 
atau memperoleh obyek tersebut. Pembelian adalah keadaan dimana individu memutuskan untuk melaksanakan transaksi yang berdasarkan pada evaluasi dan pengalaman sebelumnya. Schiffman \& Kanuk, memecah beberapa indikator minat beli menjadi 5, diantaranya: 1) Tertarik untuk mencari informasi mengenai obyek (produk), 2) Mempertimbangkan untuk membeli, 3) tertarik untuk mencoba, 4) Kepo dengan produk, 5) ingin memiliki produk. ${ }^{21}$

Pencantuman label halal produk dilakukan untuk memberikan perlindungan kepada konsumen muslim, dikarenakan banyaknya permasalahan labelisasi halal pada produk-produk yang mengandung bahan-bahan yang haram untuk dikonsumsi. Contohnya: kasus Ajinomoto yang mencuat setelah ditemukannya enzim babi dalam proses pembuatannya. Untuk mengantisipasi hal tersebut maka dalam proses produksi diperlukannya ketentuan-ketentuan syarat kehalalan suatu produk secara syara.

Dengan adanya label halal yang tercantum pada kemasan produk, maka secara langsung akan memberikan pengaruh bagi konsumen khususnya masyarakat muslim untuk menggunakan produk tersebut. munculnya rasa aman dan nyaman dalam mengonsumsi produk tersebut akan meningkatkan kepercayaan serta minat belinya.

\section{Keputusan Pembelian}

Menurut Kotler \& Keller, keputusan membeli adalah serangkaian tahapan yang dilakukan oleh konsumen sebelum melakukan keputusan pembelian suatu produk. $^{22}$ Sedangkan Setiadi, perilaku membeli mengandung makna yakni kegiatan-kegiatan individu secara langsung terlibat dalam pertukaran uang dengan barang dan jasa serta dalam proses pengambilan keputusan yang menentukan kegiatan tersebut. ${ }^{23}$ Sedangkan indikator keputusan pembelian menurut Murni \& Soeprihanto, sebanyak tujuh, antara lain: 1) Keputusan tentang jenis produk, 2) Keputusan tentang bentuk produk, 3) Keputusan tentang merek, 4) Keputusan tentang penjualan, 5) Keputusan tentang jumlah produk, 6) Keputusan tentang waktu pembelian, 7) Keputusan tentang cara pembayaran. ${ }^{24}$

\footnotetext{
${ }^{21}$ Schiffman, \& Kanuk. (2000). Consumer Behaviour 7 E. new jersey: Prenhalindo.

${ }^{22}$ Kotler, P., \& Keller, K. L. (2016). MarkKotler, P., \& Keller, K. L. In Global Edition. https://doi.org/10.1080/08911760903022556

${ }^{23}$ Setiadi, N. J. (2010). Perilaku Konsumen. Jakarta: Kencana. 9.

24 Murni, S., \& Soeprihanto, J. (2010). Pengantar Bisnis (Dasar-dasar Ekonomi
} 


\section{METODOLOGI}

Berdasarkan perumusan masalah dan tujuan penelitian, maka jenis penelitian yang digunakan adalah penelitian penjelasan (explanatory research). Penelitian ini menggunakan pendekatan kuantitatif dengan metode survei. Penelitian ini nantinya akan mengetahui pengaruh antara variabel yang telah ditentukan yaitu Label halal (X1), Harga (X2), Minat Beli (Y1) dan Keputusan Pembelian (Y2). Lokasi penelitian ini dilaksanakan di Kabupaten Pasuruan Jawa Timur, khususnya pada seluruh retailer besar produk makanan olahan UKM Kabupaten Pasuruan yang terindeks Koperasi, UKM, Pusat Oleh-oleh, Toserba. Adapun retailer tersebut antaralain; Bipang Jangkar Factory, Orion Khas Pasuruan dan Matahari Bakery, Tape, Pia, Kerupuk wedi. Alasan memilih indeks lokasi tersebut dikarenakan Kabupaten Pasuruan belum memiliki Outlet khusus untuk produk-produk UKM yang tersentral, serta belum ada kebijakan yang tertulis, terkait sertifikasi produk halal.

Populasi adalah keseluruhan wilayah generalisasi yang terdiri atas obyek atau subyek yang mempunyai kualitas dan karakteristik tertentu yang ditetapkan oleh peneliti untuk dipelajari dan kemudian ditarik kesimpulan. ${ }^{25}$ Populasi dalam penelitian ini adalah seluruh konsumen produk toko oleholeh Khas Pasuruan. Adapun jenis sampel dalam penelitian ini sama halnya dengan penelitian yang dilakukan oleh Rakhmawati, Nizar, \& Rahardjo, yakni convinence sampling. ${ }^{26}$ Mengingat populasi tersebut tidak dapat diketahui jumlahnya, dan sasarannya merupakan pembeli pada 13 toko oleholeh khas Pasuruan maka jumlah sampel yang ditentukan adalah 100 orang. Sehingga setiap konsumen yang datang memiliki kesempatan sebagai sampel penelitian.

Dalam penelitian ini data yang digunakan adalah data primer yakni data yang didapat dari sumber pertama. Dalam penelitian ini data primer diperoleh dari jawaban kuesioner yang telah diisi oleh. Sumber data primer dari penelitian ini adalah konsumen retailer oleh-oleh khas Kabupaten Pasuruan. Pengumpulan data menurut Nazir adalah prosedur yang sistematis dan standar untuk memperoleh data yang diperlukan. Dalam penelitian ini

\footnotetext{
Perusahaan). Yogyakarta: Liberty.

${ }^{25}$ sugiyono. (2014). Metode penelitian. Metode Penelitian. 66

${ }^{26}$ Rakhmawati, A., Nizar, M., \& Rahardjo, K. (2019). Green Supply Chain Management and SME's, A Qualitative Study in Indonesian Marketplace. Journal of International Conference Proceedings, 2(1).
} 
pengumpulan data akan melalui kuesioner dengan mendatangi konsumen produk, mahasiswa, PNS, Guru di Kabupaten Pasuruan. ${ }^{27}$

Uji validitas dilakukan berkenaan dengan ketepatan alat ukur terhadap konsep yang diukur sehingga benar-benar mengukur apa yang sebenarnya diukur. Uji validitas dalam penelitian ini menggunakan Pearson Product Moment. Uji Reliabilitas dilakukan untuk mendaptkan tingkat ketepatan (keandalan atau keajegan) alat pengumpul data (instrumen) yang digunakan. Uji Reliabilitas instrumen dilakukan dengan rumus Alpha. Uji Reliabilitas dalam penelitian ini menggunakan rumus Alpha.

Analisis statistik inferensial bertujuan untuk melakukan pengujian konsepsi yang dinyatakan dalam hipotesis penelitian Ferdinand.$^{28}$ Sesuai dengan hipotesis yang telah dirumuskan, maka analisis data yang digunakan dalam penelitian ini adalah Path Analisis (Analisis Jalur). Analisis jalur adalah suatu teknik untuk menganalisis hubungan sebab akibat yang terjadi pada regresi berganda jika variabel bebasnya mempengaruhi variabel tergantung tidak hanya secara langsung, tetapi juga secara tidak langsung. Lebih lanjut, analisis jalur mempunyai kedekatan dengan regresi berganda. Dengan kata lain, regresi berganda merupakan bentuk khusus dari analisis jalur. Penelitian ini menggunakan analisis jalur sebagai teknik analisis data dengan software SPSS for Windows Version 17.0. Alasan penggunaan analisis jalur sebagai alat analisis adalah path analisis merupakan metode analisis pola hubungan antar variabel dengan tujuan untuk mengetahui pengaruh langsung maupun tidak langsung seperangkat variabel bebas terhadap variabel terikat, karena itu sesuai dengan rumusan masalah dan tujuan dalam penelitian ini.

\section{PEMBAHASAN}

\section{Pengaruh Label Halal Terhadap Minat Beli}

Dalam penelitian ini diperoleh bahwa terdapat hubungan positif signifikan antara variabel label halal terhadap minat beli dengan koefisien korelasi sebesar 0,193 atau sebesar 19,3\%, yang artinya bahwa ketika variabel label halal ditingkatkan sebesar satu kali, maka variabel minat beli akan meningkat pula sebesar 19,3\%.

\footnotetext{
${ }^{27}$ Nazir, M. (2011). Metode Penelitian. Bogor: Ghalia Indonesia. 71.

${ }^{28}$ Ferdinand, A. (2003). Manajemen Pemasaran: Sebuah Pendekatan Stratejik. Research Paper Series. https://doi.org/10.1007/BF02735719
} 
$320\}\{$ Pengaruh Label Halal Majelis Ulama Indonesia (MUI), Harga, pada

Label halal merupakan bukti kehalalan sebuah produk berdasyarkan syariat islam. label halal tentunya sangat di prioritaskan pada konsumen/ masyarakat muslim terutama dalam bidang makanan sehingga seringkali dijadikan prasyarat utama dalam melakukan pembelian sebuah produk.

Hasil penelitian ini sejalan dengan penelitian yang dilakukan oleh Yuli yang dilakukan survey pada perilaku hidup sehat di Kabupaten Sarolangun, ${ }^{29}$ dan penelitian yang dilakukan oleh Neli pada konsumen tahubaxo's di Unggaran Dari hasil tersebut dapat disimpulkan bahwa konsumen lebih meminati produk yang berlabelkan halal daripada produk yang tidak memiliki label halal dikarenakan di konsumen yang mengunjungi oleh-oleh khas Pasuruan tergolong mayoritas muslim, sehingga mereka lebih yakin apabila terdapat label halal, label komposisi dan nutrisi pada suatu produk

\section{Pengaruh Harga terhadap Minat Beli}

Harga merupakan suatu hal yang tergolong sangat dasar bagi konsumen dalam melakukan pembelian sehingga harga erat kaitannya dengan perilaku keputusan pembelian konsumen. Hal tersebut sejalan dengan penelitian ini, yang diperoleh hasil bahwa terdapat hubungan positif signifikan antara variabel harga terhadap minat beli dengan koefisien korelasi sebesar 0,747 atau sebesar 74,7\%, yang artinya bahwa ketika variabel harga ditingkatkan sebesar satu kali (dalam artian terjangkau, kualitas dan manfaat sangat baik), maka variabel minat beli akan meningkat pula sebesar $74,7 \%$.

Hasil penelitian ini sejalan dengan penelitian yang dilakukan oleh Ruri \& Hendra yang dilakukan survey pada konsumen sayuran organik di pasar Sambas Medan. Dari hasil tersebut terjawab bahwa berdasarkan paradigma masyarakat luas, harga memang menjadi prioritas utama konsumen dalam memlihi dan meminati suatu produk.

\section{Pengaruh Label Halal terhadap Keputusan Pembelian}

Dalam penelitian ini diperoleh bahwa terdapat hubungan positif tidak signifikan antara variabel label halal terhadap keputusan pembelian dengan koefisien korelasi sebesar 0,015 atau sebesar 0,15\%, yang artinya

\footnotetext{
${ }^{29}$ Nurmalia, K. (2018). PERILAKU HIDUP SEHAT ANAK DITINJAU DARI SEGI MAKANAN.
} 
bahwa ketika variabel label halal ditingkatkan sebesar satu kali, maka variabel keputusan pembelian tidak memiliki dampak yang signifikan.

Hasil penelitian ini sejalan dengan penelitian yang dilakukan oleh Kamilah. kami, hal ini dikarenakan masyarakat Kabupaten Pasuruan yang menjadi konsumen oleh-oleh khas Pasuruan dalam memutuskan pembelian secara umum tidak didasari oleh label halal pada produk. Hal ini dikarenakan mayoritas pemilik UKM dan msayarakat Pasuruan mayoritas beragama muslim sehingga mereka yakin bahwa apa yang diperjual belikan juga merupakan produk yang sesuai syariat islam, pertimbangan keputusan pembelian konsumen oleh-oleh khas Pasuruan dalam penelitian ini adalah Harga dan jenis produk yang banyak diminati saja.

Kurang sadarnya konsumen dan produsen akan produk berlabel halal ini juga didukung oleh sekretaris BAKESBANG Pasuruan (Taufik Ahmad M.Si), pada hari rabu 03 September 2019 "di Kabupaten Pasuruan masih sangat kurang mengenai sosialisasi pentingnya produk halal pada UKM dan masyarakat, oleh sebab itu periode tahun 2019-2020 akan lebih di galakkan lagi untuk penerapannya".

\section{Pengaruh Harga terhadap Keputusan Pembelian}

Dalam penelitian ini diperoleh bahwa terdapat hubungan positif signifikan antara variabel harga terhadap keputusan pembelian dengan koefisien korelasi sebesar 0,109 atau sebesar 10,9\%, yang artinya bahwa ketika variabel harga ditingkatkan sebesar satu kali, maka variabel keputusan pembelian akan meningkat pula sebesar 10,9\%.

Hasil penelitan mengenai hubungan positif antara variabel Harga dengan keputusan pembelian telah dilakukan oleh Elisa Desy Rinda Putri, pengruh kualitas produk dan harga terhadap keputusan pembelian melalui minat beli, studi pada konsumen wardah di Yogyakarta. Berdasarkan hasil penelitian tersebut, dapat diperoleh kesimpulan bahwa pertimbangan konsumen oleh-oleh khas Kabupaten Pasuruan untuk memutuskan membeli adalah harga, setlah memutuskan produk apa yang diminati, karena dalam penelitian ini koeisien terbesar dalm memutuskan pembelian adalah minat beli, sehingga konsumen terlebih dahulu memilih produk yang diminati, baru memikirkan harganya untuk melakukan keputisan pembelian. 


\section{Pengaruh Minat Beli terhadap Keputusan Pembelian}

Dalam penelitian ini diperoleh bahwa terdapat hubungan positif signifikan antara variabel minat beli terhadap keputusan dengan koefisien korelasi sebesar 0,873 atau sebesar 87,3\%, yang artinya bahwa ketika variabel minat beli ditingkatkan sebesar satu kali, maka variabel keputusan pembelian akan meningkat pula sebesar $87,3 \%$.

Hasil penelitan mengenai hubungan positif antara variabel minat beli terhadap keputusan pembelian sejalan dengan penelitian yang telah dilakukan oleh Maghfiroh, Arifin dan Sunarti tekait miant beli kosmetik di Malang dan minat beliair mineral Jakarta Barat. Dari seluruh hasil penelitian tersebut dapat di simpulkan bahwa minat pembelian terhadap suatu produk terutama pada konsumen oleh-oleh makanan Khas Pasuruan didominasi oleh merupakan faktor utama dalam mendorong konsumen untuk melakukan keputusan pembelian.

\section{Pengaruh Label Halal terhadap Keputusan Pembelian Melalui Minat Beli}

Dalam penelitian ini diperoleh bahwa terdapat hubungan positif signifikan antara variabel label halal terhadap keputusan pembelian melalui minat beli dengan koefisien korelasi sebesar 0,171 atau sebesar $17,1 \%$, yang artinya bahwa ketika variabel label halal dan minat beli ditingkatkan sebesar satu kali, maka variabel keputusan pembelian akan meningkat pula sebesar $87,3 \%$.

\section{Pengaruh Harga terhadap Keputusan Pembelian Melalui Minat Beli}

Dalam penelitian ini diperoleh bahwa terdapat hubungan positif signifikan antara variabel harga terhadap keputusan pembelian melalui minat beli dengan koefisien korelasi sebesar 0,652 atau sebesar 65,2\%, yang artinya bahwa ketika variabel harga dan minat beli ditingkatkan sebesar satu kali, maka variabel keputusan pembelian akan meningkat pula sebesar $65,2 \%$. Hasil penelitan mengenai hubungan positif antara variabel harga dan keputusan pembelin melalui minat beli ini di dukung oleh penelitian Ria pada konsumen air mineral di Jakarta Barat.

\section{KESIMPULAN}

Berdasarkan pembahasan yang telah diuraikan sebelumnya, maka dari penelitian ini dapat ditarik kesimpulan sebagai berikut:

a. Label halal memiliki pengaruh yang positif signifikan terhadap minat beli pada konsumen di 12 toko oleh-oleh makanan khas Pasuruan. Semakin 
tinggi label halal produk pada suatu toko, maka akan semakin tinggi pula minat konsumen terhadap produk-produk di toko tersebut. Apabila label halal rendah maka semakin rendah pula minat beli konsumen pada produk di toko tersebut

b. Harga memiliki pengaruh yang positif signifikan terhadap minat beli pada konsumen di 12 toko oleh-oleh makanan khas Pasuruan. Semakin baik harga suatu produk akan semakin tinggi pula minat beli. Apabila aspek harga semakin buruk (mahal, tidak sesuai dengan manfaat dan kualitas) maka semakin rendah pula minat beli pada produk.

c. Label halal memiliki pengaruh yang positif tidak signifikan terhadap keputusan pembelian pada konsumen di 12 toko oleh-oleh makanan khas Pasuruan. Semakin tinggi produk yang memiliki label halal maka tidak berdampak pada keputusan konsumen untuk membeli produk tersebut, hal itu dikarenakan gaya hidup, pemahaman, dan faktor lain yang menjadi pertimbangan konsumen dalam memutuskan untuk membeli produk.

d. Harga memiliki pengaruh yang positif signifikan terhadap keputusan pembelian pada konsumen di 12 toko oleh-oleh makanan khas Pasuruan. Semakin baik suatu harga produk maka akan semakin tinggi pula keputusan pembelian konsumen terhadap produk tersebut. Apabila aspek harga semakin buruk (mahal, tidak sesuai dengan manfaat dan kualitas) maka semakin rendah pula keputusan pembelian konsumen terhadap produk tersebut.

e. Minat beli memiliki pengaruh yang positif signifikan terhadap keputusan pembelian pada pada konsumen di 12 toko oleh-oleh makanan khas Pasuruan. Semakin tinggi minat beli atas suatu produk, maka akan semakin tinggi pula keputusan pembelian. Apabila minat beli konsumen rendah maka semakin rendah pula keputusan pembelian atas produk oleholeh khas Pasuruan.

f. Label halal memiliki pengaruh yang positif signifikan terhadap keputusan pembelian melalui minat beli, hal tersebut berarti variabel minat beli berhasil memediasi sempurna hubungan label halal terhadap keputusan pembelian.

g. Harga memiliki pengaruh positif signifikan terhadap keputusan pembelian melalui minat beli, hal tersebut berarti variabel minat beli berhasil memediasi sempurna hubungan harga terhadap keputusan pembelian. 
$324\}\{$ Pengaruh Label Halal Majelis Ulama Indonesia (MUI), Harga, pada

\section{DAFTAR PUSTAKA}

Abd Latif, I., Mohamed, Z., Rezai, G., \& Kamarulzaman, N. (2013). The impact of food labeling on purchasing behavior among Non-Muslim consumers in Klang Valley. Australian Journal of Basic and Applied Sciences.

Abdul, M., Ismail, H., Hashim, H., \& Johari, J. (2009). Consumer decision making process in shopping for halal food in Malaysia. China-USA Business Review.

Al-Asyhar, T. (2003). Bahaya Makanan Haram bagi Kesehatan Jasmani dan Kesucian Rohani. Jakarta: PT Al-Mawardi Prima.

Al-Ghazali, I. (2002). Benang Tipis Antara Halal dan Haram. Pasuruan: Putra Pelajar.

Fatmasari Sukesti, \& Mamdukh Budiman. (2014). the Influence Halal Label and Personal Religiousity on Purchase. International Journal of Business, Economics and Law.

Ferdinand, A. (2003). Manajemen Pemasaran: Sebuah Pendekatan Stratejik. Research Paper Series. https://doi.org/10.1007/BF02735719

Girindra, A. (1998). LP POM MUI Sejarah Sertifikasi Halal. Jakarta: LP POM.

H, A. (1992). Consumer Behavior \& Marketing Action. PWS: Kent publishing company.

Hamid, A. (2012). Buku Pintar Halal Haram Sehari-hari. Yogyakarta: Diva Press.

Hastuti, E. R. (2017). Analisis Penetapan Kewajaran Harga Pada Pembiayaan Rahn di Bank Mandiri Syariah. Jurnal Justisia Ekonomika: Magister Hukum Ekonomi Syariah. https://doi.org/10.30651/justeko.v1i01.1126

Kotler. (2013). Manajemen Pemasaran Jilid 2. In Penerbit Erlangga.

Kotler, P., \& Keller, K. L. (2016). MarkKotler, P., \& Keller, K. L. In Global Edition. https://doi.org/10.1080/08911760903022556

Murni, S., \& Soeprihanto, J. (2010). Pengantar Bisnis (Dasar-dasar Ekonomi Perusahaan). Yogyakarta: Liberty.

Nazir, M. (2011). Metode Penelitian. Bogor: Ghalia Indonesia.

Nizar, M. (2016). Proses Entrepreneurship, Kolaborasi Inovasi, Penciptaan Kekayaan di dalam Organisasi Bisnis. Jurnal Istiqro, 2(2), 91-103.

Rafita, H. Z. (2015). Pengaruh Label Halal Terhadap Keputusan Pembelian Produk Kosmetik (Studi Pada Mahasiswi Fakultas Ekonomi Dan Bisnis Islam Angkatan 2013- 2016 UIN Raden Intan Lampung). https://doi.org/10.1017/ CBO9781107415324.004

Rakhmawati, A., Kusumawati, A., Rahardjo, K., \& Muhammad, N. (2020). The role of government regulation on sustainable business and its influences on performance of medium-sized enterprises. Journal of Sustainability Science and Management. 
Rakhmawati, A., Nizar, M., \& Rahardjo, K. (2019). Green Supply Chain Management and SME's, A Qualitative Study in Indonesian Marketplace. Journal of International Conference Proceedings, 2(1).

Schiffman, \& Kanuk. (2000). Consumer Behaviour 7 E. new jersey: Prenhalindo.

Setiadi, N. J. (2010). Perilaku Konsumen. Jakarta: Kencana.

Sugiyono, P. D. metode penelitian kuantitatif, kualitatif,dan R\&D. , Alfabeta, cv. (2016).

Syahputra, A., \& Hamoraon, H. (2014). Pengaruh Labelisasi Halal Terhadap Keputusan Masyarakat Kecamatan Perbaungan Dalam Pembelian Produk Makanan Dalam Kemasan. Jurnal Ekonomi Dan Keuangan.

Vargas-rechia, C. G., Reicher, F., Sierakowski, M. R., Heyraud, A., Driguez, H., Szymanska-chargot, M., ... Asadpur, G. (2015). A profile of the South African table grape market value chain. Bioresource Technology. https://doi.org/10.1016/j.jaap.2016.09.004

Weenas, J. (2013). Kualitas Produk, Harga, Promosi Dan Kualitas Pelayanan Pengaruhnya Terhadap Keputusan Pembelian Spring Bed Comforta. Jurnal Riset Ekonomi, Manajemen, Bisnis Dan Akuntansi.

William, J. S. (2004). Prinsip-prinsip Pemasaran (Erlangga, Ed.). Jakarta.

Wilson, J. A. J. (2014). The halal phenomenon: An extension or a new paradigm? Social Business. https://doi.org/10.1362/2044408 $14 \times 14103454934294$

Zulaekah, S., \& Kusumawati, Y. (2016). Halal dan Haram dalam Islam. Suhuf. 
$326\}\{$ Pengaruh Label Halal Majelis Ulama Indonesia (MUI), Harga, pada

..::: Malia: Jurnal Ekonomi Islam, Volume 11 Nomor 2 Juni 2020 :::.. 